MAREK HENDEL

\title{
MIEJSCE ZJAWISKA WSPÓŁDZIELENIA W KONCEPCJI ZRÓWNOWAŻONEGO ROZWOJU
}

\section{WPROWADZENIE}

Współdzielenie ${ }^{1}$ uważa się za rewolucyjne zjawisko w gospodarce ${ }^{2}$. Zwraca się przy tym uwagę na sam akt dzielenia i związanych z nim kilka kwestii ${ }^{3}$ : dzielenie się to udostępnianie posiadanych zasobów innym, a także przyjmowanie zasobów niebędących własnościa; występuje różnica między dzieleniem, w którym występuje transfer praw własności, a udostępnianiem danego zasobu na określony czas; dzielenie się ma swoje społeczne znaczenie, które można intepretować jako trzeci element organizacji produkcji (obok rynków i państwa). W ujęciu praktycznym dzielenie się wiąże się z faktem niewykorzystywania w pełni zasobów, posiadania pewnych jego „nadwyżek” i ochoty dzielenia się nimi ${ }^{4}$. Dlatego współdzielenie tłumaczy się jako zmianę orientacji ludzkiej z chęci posiadania dóbr na własność (by móc z nich skorzystać) na rzecz korzystania z dóbr na bazie ich dostępności, co może być traktowane jako nowa forma własności/ posiadania ${ }^{5}$.

Śmiało można zatem uznać, że powyższe podejście wpisuje się w ideę zrównoważonego rozwoju. Od lat trwa jednak dyskusja nad prawdziwym obliczem zjawiska współdzielenia. Z jednej strony pojawiają się głosy, że jest to zjawisko komercjalizujące aspekty życia będące dotychczas poza zasięgiem rynku, i tym samym staje się nową formą neoliberalnego kapitalizmú. Z drugiej współdzielenie coraz częściej wymieniane jest jako nowy środek promowania praktyk zrównoważonego rozwoju ${ }^{7}$. Dlatego powyższe wątpliwości stały się przyczyną podjęcia rozważań, których celem jest określenie miejsca zjawiska

\footnotetext{
${ }^{1}$ Pomimo licznych propozycji tłumaczenia angielskiego słowa „sharing” na język polski w ujęciu zjawiska ekonomicznego odnoszącego się do dóbr (m.in. „współdzielenie”, „współuczestnictwo”, „współużytkowanie”) w zdecydowanej większości krajowych prac naukowych badacze posługują się słowem „współdzielenie”. Biorąc to pod uwagę oraz powszechne trudności z interpretacją samego zjawiska, co wiąże się z nieustannie pojawiającymi się nowymi tłumaczeniami i wskazywaną koniecznością usystematyzowania pojęć, słowo „współdzielenie” uznano w pracy za najwłaściwsze tłumaczenie.

${ }^{2}$ Rifkin (2014): 19; Leszczyńska, Łopaciński (2017): 73.

${ }^{3}$ Sztokfisz (2017): 92.

${ }^{4}$ Sobiecki (2016): 30.

${ }^{5}$ Ziobrowska (2017): 262.

${ }^{6}$ Martin (2016): 149-159.

${ }^{7}$ Heinrichs (2013): 228-231; Scholz (2014): 51-52; Daunorienė et al. (2015): 836-841.
} 
współdzielenia w koncepcji zrównoważonego rozwoju. Zastosowaną metoda badawczą umożliwiająca osiągnięcie przyjętego celu była analiza krytyczna literatury, zwłaszcza z zakresu nauk ekonomicznych - starano się przy tym zachować charakter interdyscyplinarny doboru literatury ze względu na zakres przedmiotowy pracy dotyczący zrównoważonego rozwoju.

\section{ZJAWISKO WSPÓŁDZIELENIA - UJĘCIE TEORETYCZNE}

Współdzielenie dóbr jest praktyką społeczną znaną od wieków i jest podstawowym zachowaniem konsumenckim (mylonym z wymianą towarów, dawaniem prezentów). Klasyczny jego model opiera się na spotkaniu twarza w twarz, co nieustannie odbywa się po dziś dzień w społecznościach na całym świecie, dotyczy to zwłaszcza osób sobie bliskich (rodzina, przyjaciele, sassiedzi) ${ }^{8}$. Od niedawna natomiast, między innymi za sprawą komercjalizacji rynku i rozwoju technologii, akt ten nabiera nowych form i znaczeń ${ }^{9}$, a trendy oparte na współdzieleniu dóbr, takie jak gospodarka kolaboratywna (ang. collaborative economy) ${ }^{10}$ oraz gospodarka współdzielenia (ang. sharing econo$m y)^{11}$, uważa się za rewolucyjne $\mathrm{w}$ ujęciu zmian współczesnego świata ${ }^{12}$. We wspomnianym klasycznym modelu współdzielenia zaczynają bowiem pojawiać się pośrednicy, którzy umożliwiają i ułatwiają tego typu działania w czasie rzeczywistym na skalę globalną. To dzięki pośrednikom odblokowywana jest możliwość współdzielenia wolnych zasobów (m.in. miejsca noclegowe, usługi transportowe, narzędzia, zabawki, książki), co oferuje przy tym korzyści dla każdej ze stron, czasem bez konieczności spotkania ${ }^{13}$.

Początków dyskusji nad pojęciem w zakresie nauk ekonomicznych badacze doszukuja się $\mathrm{w}$ pracach $\mathrm{z}$ lat pięćdziesiątych XX w., opracowywanych w ramach nurtu twórczości teoretycznej i badawczej „human ecology” (ekologia ludzka, ekologia społeczna). Opisywane wówczas zjawiska dotyczyły wspól-

8 Böckmann (2013).

9 Belk (2010): 715-717.

${ }^{10} \mathrm{~W}$ odróżnieniu od stosowanego przez polskich badaczy słowa kolaboratywny w ujęciu konsumpcji (ang. collaborative consumption) w większości polskich prac badawczych do opisywania zjawiska gospodarki (ang. collaborative economy) używa się terminu „gospodarka współpracy”. Takie podejście uniemożliwia wypracowanie wspólnego podejścia do opisywania zjawisk. Dlatego autor proponuje stosowanie terminu „gospodarka kolaboratywna”, której częścią jest choćby konsumpcja kolaboratywna.

$11 \mathrm{~W}$ polskiej literaturze w obu pojęciach używane jest zamiennie określenie „ekonomia” („ekonomia współpracy”, „ekonomia współdzielenia”). Tymczasem - jak słusznie zauważają Czernek i Wójcik (2017: 66) na podstawie syntezy definicji słów „ekonomia” oraz „gospodarka” - angielskie sformułowania opisywanych zjawisk odnoszą się w języku polskim do gospodarki, nie zaś do ekonomii (ang. economics). Słowo „gospodarka” stanowi bowiem system, formę prowadzonej działalności, system mechanizmów i warunków działania podmiotów, z kolei „ekonomia” - zidentyfikowane zasady i reguły, pozwalające je opisać.

12 Rostek, Zalega (2015): 12.

13 Sun et al. (2016). 
nych i skoordynowanych ludzkich działań bazujących na społecznościach ${ }^{14}$. Zainteresowanie zagadnieniem współdzielenia wzrosło $\mathrm{w}$ latach siedemdziesiątych i osiemdziesiątych XX w. za sprawa poruszanych w pracy Marcusa Felsona i Joego L. Spaetha ${ }^{15}$ zagadnień związanych ze współdzieleniem dóbr z innymi konsumentami. Wówczas po raz pierwszy sformułowano pojęcie konsumpcji kolaboratywnej (ang. collaborative consumption), które zgodnie z teoria struktury wspólnoty i występującej w niej współzależności Amosa Hawleya starano się wyjaśnić jako akt korzystania z dóbr i usług wraz z innymi osobami ${ }^{16}$. W dążeniu do zrozumienia zachodzacych globalnych przemian w ramach współdzielenia dóbr istotne stają się współcześnie rozważania w ramach dwóch najczęściej wymienianych trendów w gospodarce opartych na tym zjawisku - gospodarki kolaboratywnej oraz gospodarki współdzielenia ${ }^{17}$.

Teoria opisująca gospodarkę kolaboratywną powstała w odpowiedzi na funkcjonowanie różnych określeń definiujących powstały fenomen na rynku opierający się na zjawisku współdzielenia (identyfikuje się ich ok. 40) i próbę ich oddania jednym ogólnie przyjętym terminem ${ }^{18}$. Zgodnie $\mathrm{z}$ interpretacja Rachel Botsman ${ }^{19}$, uznawaną w literaturze przedmiotu za najbliższą wyjaśnieniu pojęcia, gospodarka kolaboratywna oznacza ,[...] gospodarkę zbudowana na rozproszonych sieciach połączonych jednostek i społeczności jako przeciwieństwo do scentralizowanych instytucji, transformująca sposób, w jaki można produkować, konsumować, finansować i uczyć się".

Gospodarka współdzielenia oznacza natomiast „[...] model społeczno-gospodarczy, oparty na oddolnych inicjatywach indywidualnych osób (relacje P2P), które odnoszą się do nie w pełni wykorzystanych zasobów i bazują na współdzieleniu realizowanym poprzez platformy technologiczne, za opłatą lub bezpłatnie" ${ }^{20}$. W definicji tej nacisk kładzie się wyłacznie na relację P2P, która nie jest jednak jedyną w gospodarce współdzielenia ${ }^{21}$. Niezależnie jednak od ujęcia relacji w gospodarce współdzielenia, integralnym jej elementem jest niewykorzystany w pełni zasób, którego specyfika definiowana jest w dość podobny sposób.

W literaturze przedmiotu istnieje wiele interpretacji gospodarki współdzielenia, która dość często definiuje się, obejmując zakresem pojęciowym gospodarkę kolaboratywną i traktując ją jako synonim tej ostatniej. Tymczasem to właśnie gospodarka kolaboratywna uważana jest za najszersze pojęcie opisujące trendy w gospodarce wpisujące się w zjawisko współdzielenia, między innymi gospodarkę współdzielenia ${ }^{22}$. Ponadto - jak słusznie zauważa

\footnotetext{
14 Dredge, Gyimóthy (2015): 289.

15 Felson, Spaeth (1978).

16 Sztokfisz (2017): 91.

17 Owyang et al. (2013); Zgiep (2014); Koopman et al. (2015); Hatzopoulos, Roma (2017).

18 Jastrzębska, Legutko-Kobus (2017): 445.

19 Botsman (2013).

20 Czernek, Wójcik (2017): 68.

21 Schor (2016): 5.

22 Stokes et al. (2014); Budziewicz-Guźlecka (2017); Koźlak (2017); Czernek et al. (2018).
} 
Jan Zygmuntowski ${ }^{23}$ - gospodarka współdzielenia jest jedynie wąskim wycinkiem rzeczywistości związanej z samym zjawiskiem współdzielenia.

W świetle przedstawionych rozważań istotne jest zatem zwrócenie szczególnej uwagi na różnice, jakie występują między pojęciami, często traktowanymi jako synonimy: gospodarka kolaboratywna i gospodarka współdzielenia. Niezależnie jednak od dyskusji nad oboma kategoriami, ich podstawę stanowi opisane zjawisko współdzielenia, które współcześnie nabiera nowego znaczenia ze względu na nowe formy występowania.

\section{GŁÓWNE ZAŁOŻENIA KONCEPCJI ZRÓWNOWAŻONEGO ROZWOJU}

Od momentu pojawienia się koncepcji zrównoważonego rozwoju powszechność stosowania tego pojęcia w literaturze naukowej, aktach prawnych czy dokumentach strategicznych zrodziła poważne wątpliwości związane z jego właściwym definiowaniem i interpretacja, prowadząc do niejednoznaczności i ogólnikowości terminu ${ }^{24}$. Pomimo wieloletniej dyskusji nad koncepcja samo pojęcie nie posiada jednej precyzyjnie sformułowanej i powszechnie akceptowanej definicji, co wynika głównie ze sposobu tłumaczenia angielskiego terminu „sustainable”. Próba wyliczenia powstałych dotychczas interpretacji oscyluje w granicach kilkuset pozycji ${ }^{25}$. Tak duże zróżnicowanie staje się problematyczne nie tylko ze strony teoretycznej i poznawczej, ale przede wszystkim praktycznej ${ }^{26}$.

Odwołując się do wieloznaczności pojęcia sustainable, ekonomiczna interpretacja zrównoważonego rozwoju obejmuje przede wszystkim zestaw kategorii przypisanych do trzech cech rozwojowych: trwałości, zrównoważenia i samopodtrzymywania ${ }^{27}$. Zagadnienie to jest jednak częścią dyskusji w środowisku naukowym, utrudnia właściwe rozumienie oraz stosowanie poszczególnych pojęć ${ }^{28}$. Dlatego dyskusja nad interpretacją pojęcia dotyczy głównie tego, co powinno się znaleźć w koncepcji i jakie obszary obejmować. Podstawowymi kwestiami w tym przypadku, według Dariusza Kiełczewskiego ${ }^{29}$, sa: trwałość zaspokajania potrzeb w wymiarze międzypokoleniowym; pokoleniowe postrzeganie problemu zaspokojenia potrzeb; sprawiedliwość wewnątrzpokoleniowa oraz sprawiedliwość międzypokoleniowa.

Realizacja celów związanych z wyżej wymienionymi stanowi z kolei o cechach zrównoważonego rozwoju. Jasper Grosskurth oraz Jan Rotmans ${ }^{30}$, ana-

\footnotetext{
${ }^{23}$ Zygmuntowski (2017): 14.

24 Stanny, Czarnecki (2011): 13.

25 Tornjanski et al. (2017): 79.

26 Jeżowski (2012): 101-102.

27 Kiełczewski (2010): 21.

28 Borys (2014): 10.

${ }^{29}$ Kiełczewski (2011): 29.

${ }^{30}$ Grosskurth, Rotmans (2005): 136-138.
} 
lizując treść interpretacji i definicji zrównoważonego rozwoju, wyróżniaja z cztery cechy koncepcji, takie jak: międzypokoleniowość, a więc uwzględnienie kwestii czasowej w dyskusji i realizacji zrównoważonego rozwoju w ujęciu kilku pokoleń; poziomowość skali, wyrażona różnym poziomem realizowania koncepcji (poziom globalny, regionalny, lokalny); wieloaspektowość, odnosząca się do charakteru zrównoważonego rozwoju opartego na trzech podstawowych sferach oddziaływania - ekonomicznego, społeczno-kulturowego oraz środowiskowego (pomimo ich odrębności, realizacja koncepcji wymaga zachowania zasady współzależności); wielotorowość interpretacji, wymagająca od każdej z interpretacji diagnozy aktualnych i przyszłych potrzeb społeczeństw.

Poza opisanymi wyżej celami, zasadami oraz cechami zrównoważonego rozwoju, istotne znaczenie dla konkretyzacji koncepcji ma pojęcie ładu, który w podstawowym ujęciu określany jest w obszarze społecznym, ekonomicznym oraz środowiskowym ${ }^{31}$. Pojęcie ładu definiuje Wiesław Sztumski ${ }^{32}$; określa on ład jako taką organizację systemu społecznego, dzięki której możliwe jest zgodne (harmonijne) funkcjonowanie jego elementów w taki sposób, aby system jako całość mógł skutecznie realizować swoją funkcję celu oraz wykonywać zadanie, do którego jest powołany. Szczególną propozycją w tym przypadku jest ład zintegrowany, który można rozumieć za Tadeuszem Borysem jako ,[...] pozytywny stan docelowy zmian rozwojowych łączący w spójny, niesprzeczny sposób łady składowe, czyli jest benchmarkingowym sposobem wyrażania wzorca rozwoju lub - inaczej mówiąc - układem docelowym rozwoju zrównoważonego (benchmarkiem dla zmian rozwojowych)"33.

Większość badaczy uważa, że zrównoważony rozwój jest realizowany, gdy spełnione sa cele w obszarze społecznym, ekologicznym i ekonomicznym ${ }^{34}$. Jeffrey Sachs ${ }^{35}$ uznaje to podejście za fundament zrównoważonego rozwoju, nazywając je filarami. Osiagnięcie zrównoważonego rozwoju jest możliwe w momencie, gdy każdy z obszarów w prezentowanym układzie przybierze ostatecznie formę pakietu współzależnych od siebie elementów ${ }^{36}$. Istnieje w tym przypadku potrzeba odniesienia do wszystkich dziedzin życia i realizacji na zasadzie harmonii ${ }^{37}$. Pomimo powszechnie funkcjonujacych modeli opartych na trzech filarach, badacze zagadnienia wskazuja, że w niedługim czasie powinna nastapić ich ewolucja i powinny być one uzupełnione chociażby o filar kulturowy ${ }^{38}$, polityczno-instytucjonalny i religijno-duchowy ${ }^{39}$.

Trwajacca nieustannie dyskusja nad aspektami teoretycznymi koncepcji zrównoważonego rozwoju powoduje, że wciąż za kwestię otwartą uważa się możliwość implementacji koncepcji za pomocą różnego rodzaju instrumentów.

\footnotetext{
31 Borys (2012): 479.

32 Sztumski (2006): 74.

33 Borys (2011): 81.

34 Machowski (2003); Seyfang (2006); Sachs (2012).

35 Sachs (2012): 2211.

36 Gibson (2006): 278.

37 Finkbeiner et al. (2010).

38 Nurse (2006).

${ }^{39}$ Burford et al. (2013).
} 
Warto przy tym wskazać, co pokazuja powyższe rozważania, że obecny stan wiedzy i jego przedstawienie nie przyczyniaja się jednoznacznie do zrozumienia koncepcji, a tym bardziej jej wdrożenia. W konsekwencji trudno wskazać efekty takiego wdrożenia. Dlatego to w nowo powstających zjawiskach na rynku doszukuje się często możliwości realizacji koncepcji zrównoważonego rozwoju. Jednym z takich zjawisk jest współdzielenie objawiające się zróżnicowanymi formami występowania.

\section{ZJAWISKO WSPÓEDZIELENIA A KONCEPCJA ZRÓWNOWAŻONEGO ROZWOJU}

Przedstawiona po raz pierwszy w latach siedemdziesiątych XX w. przez Felsona i Spaetha problematyka zjawiska współdzielenia w ujęciu konsumpcji kolaboratywnej miała szczególny wydźwięk. Uznano bowiem, że to w teorii behawioralnej należy się doszukiwać podstaw interpretacji istoty tego zjawiska. Źródłem zachowań ludzkich związanych ze współdzieleniem stały się więc filozoficzne, religijne, socjologiczne i antropologiczne postawy życia, które dały poczatek naukowym dociekaniom $\mathrm{w}$ teorii ekonomii społecznej i behawioralnej $^{40}$. Z kolei rezultatem rozważań nad zjawiskiem w ekonomii społecznej i behawioralnej są wnioski, że aktywność wpisująca się we współdzielenie może się przyczyniać do efektywności wykorzystania zasobów, a także generować korzyści o charakterze środowiskowym i ekologicznym. Taka wielokierunkowość zmian nakazuje rozpatrzyć zjawisko współdzielenia w ujęciu idei zrównoważonego rozwoju, a także kształtowanej w jej założeniach ekonomii zrównoważonego rozwoju.

Zasadniczym elementem rozważań w nurcie ekonomii zrównoważonego rozwoju jest uzasadnienie i rozwiązanie problemów trudnych do wyjaśnienia przez pozostałe ekonomie cząstkowe. Za przykład posłużyć moga problemy związane z: narastaniem globalnego kryzysu ekologicznego; globalizacją i internalizacją procesów gospodarczych przy utrzymywaniu państwowych środków i instrumentów regulacji tych procesów; pogłębianiem się rozwarstwienia społecznego; kryzysem finansowym prowadzącym do zubożenia narodów, a w efekcie powstania niepokojów społecznych ${ }^{41}$. Realizacja tak postawionych celów wymaga zmian prowadzacych do zrozumienia, czym są przyroda i zasoby naturalne (ontologia), kim jest człowiek i jakie ma potrzeby oraz możliwości (antropologia), zmian sposobu wartościowania środowiska oraz osoby ludzkiej (aksjologia), jak również etyki bazującej na podstawowych zasadach sprawiedliwości między- i wewnątrzpokoleniowej ${ }^{42}$.

Zdaniem Jerzego W. Pietrewicza i Romana Sobieckiego ${ }^{43}$ współdzielenie można traktować jako filar zrównoważonego rozwoju ze względu na kilka

\footnotetext{
40 Stępnicka (2018): 47-48.

41 Poskrobko (2011): 14-15.

42 Ganowicz-Baczyk (2013): 50.

${ }^{43}$ Pietrewicz, Sobiecki (2016): 22-23.
} 
aspektów: współdzielenie uruchamia procesy przybierające charakter arbitrażu w obszarze ekonomicznym, społecznym i środowiskowym; niweluje poziomy dochodowych rozpiętości; poszerza zakres dostępu do określonych dóbr; pozwala na wyższe zaspokojenie potrzeb, realizowane przy relatywnie niskich kosztach krańcowych; zmniejsza zapotrzebowanie na nowe zasoby i związaną z tym presję na środowisko przyrodnicze; tworzy możliwości wzrostu gospodarczego bez konieczności wytworzenia nowych zasobów środków produkcji. Potencjał zjawiska widoczny jest w scenariuszach dla lokalnych i globalnych gospodarek, które zdaniem badaczy będą się rozwijały w zgodzie ze zrównoważonym rozwojem z wykorzystaniem zjawiska współdzielenia ${ }^{44}$. Warunkiem urzeczywistnienia scenariuszy jest jednak chęć zmian po stronie konsumentów ${ }^{45}$.

Podejmując rozważania na temat relacji zjawiska współdzielenia z ekonomią zrównoważonego rozwoju, warto zwrócić uwagę, że użytkownicy wybierający współdzielenie świadomie odrzucają rozwiązania optymalne na rzecz wyższych wartości, takich jak: zrównoważony rozwój, przeciwstawienie się rozrzutnemu gospodarowaniu zasobami oraz zwiększenie efektywności konsumpcji. Z jednej strony takie rozwiązania podważają główne założenia ekonomii klasycznej, dotyczace zwłaszcza ukształtowanej w tym nurcie teorii homo oeconomicus ${ }^{46}$. Trudno bowiem doszukiwać się powyższych cech użytkownika współdzielenia w określonej przez ekonomię głównego nurtu naturze ludzkiej opartej na dążeniu do posiadania, chęci konkurowania, dbania o wassko pojęty własny interes. Niezależnie od cech użytkownika warta uwagi jest także sama wymiana rynkowa, która w ramach wyróżnionego nurtu polega na dostępie do dóbr przez nabywanie prawa własności - co z kolei generuje specyficzna relację konsument-obiekt, regulujaccą postawę i zachowania jednostki wobec danego dobra (swoboda jego dysponowania, odpowiedzialność) ${ }^{47}$.

Z drugiej strony zjawisko współdzielenia traktuje się jako bodziec do powstania nowej kategorii człowieka gospodarującego z typowymi dla niej cechami i atrybutami, właściwymi z punktu widzenia tego zjawiska ${ }^{48}$. W dyskursie naukowym dotyczacym relacji współdzielenia z ekonomią zrównoważonego rozwoju od kilku lat pojawia się apel o podjęcie badań na rzecz nowej jednostki przeciwstawnej homo oeconomicus zwanej homo collaborans ${ }^{49}$. Można więc uznać, że założenia ekonomii zrównoważonego rozwoju moga być w wielu punktach spójne ze zjawiskiem współdzielenia, a na ich podstawie można dokonywać prób interpretacji zmian w środowisku społeczno-gospodarczym. Coraz częściej wskazuje się jednak na brak tak bezpośredniego związu, czego potwierdzeniem są wyniki badań naukowych prezentujące naturę konsumentów, daleką od powyższych wspólnych odniesień ${ }^{50}$.

\footnotetext{
${ }^{44}$ Cohen, Kietzmann (2014); Daunorienè et al. (2015).

45 Hamari et al. (2016): 2057-2058.

46 Sztokfisz (2017): 100-101.

47 Janczewski (2017): 263.

48 Stępnicka, Wiaczek (2018): 397.

49 Heinrichs (2013).

${ }^{50}$ Hamari et al. (2015).
} 
Warto jednak podkreślić, że to konsumenci przyczynili się nie tylko do rozwoju, ale i powstania gospodarki współdzielenia w obecnym kształcie, na co wpływ miało wiele czynników, m.in.: wszechobecność Internetu i urządzeń mobilnych, nadmierna ilość niewykorzystanych zasobów, rosnąca świadomość konsumentów w zakresie zrównoważonego rozwoju, recesja gospodarcza prowadząca do wyższych stóp bezrobocia ${ }^{51}$. Dlatego niezależnie od podejścia do omawianej relacji warto wskazać, że to wykorzystywanie marnotrawionego potencjału zasobów uważa się za cechę podstawowa gospodarki współdzielenia $^{52}$. Z tego też powodu trend gospodarki współdzielenia traktuje się jako szansę i instrument realizacji koncepcji zrównoważonego rozwoju ${ }^{53}$.

\section{PODSUMOWANIE}

Rozważania nad miejscem zjawiska współdzielenia w koncepcji zrównoważonego rozwoju pokazuja, że jest to zagadnienie bardzo złożone i trudno o jego jednoznaczne zrozumienie bez obszernego opisu. Wskazana złożoność $\mathrm{w}$ tym przypadku zwiazana jest $\mathrm{z}$ wieloma kwestiami. Dotyczy to zwłaszcza braku powszechnej akceptacji właściwej interpretacji zjawiska współdzielenia oraz trendów w gospodarce opartych na tym zjawisku, a także koncepcji zrównoważonego rozwoju. Próba interpretacji zachodzacych relacji między pojęciami może dawać pewnego rodzaju ogląd, jednakże wnioski płynące z takiego zestawienia generują nowe problemy badawcze, konieczne do rozwiązania w dalszych badaniach pogłębionych.

Warto jednak wskazać, że badacze podejmujący w swych pracach zagadnienia związane ze zrównoważonym rozwojem widzą w zjawisku współdzielenia możliwość realizacji wyróżnionej idei. Niewątpliwie zatem omawiane zjawisko w koncepcji zrównoważonego rozwoju ma swoje miejsce, konieczna jest jednak identyfikacja charakteru takiego występowania. W pracy wskazano bowiem na funkcjonujacce współcześnie dwa przeciwstawne ujęcia: od realizacji koncepcji zrównoważonego rozwoju, przez występujące formy zjawiska współdzielenia, po całkowite zaprzeczenie jej założeń. Zjawisko współdzielenia wykazuje się zatem dużym potencjałem $\mathrm{w}$ ujęciu realizacji zrównoważonego rozwoju, dlatego wydaje się, że wszystko zależy od współczesnego charakteru jego występowania na rynku.

Marek Hendel

Uniwersytet Ekonomiczny w Katowicach marek.hendel@edu.uekat.pl

https://orcid.org/0000-0001-6838-597X

\footnotetext{
51 Parente et al. (2018).

52 Stokes et al. (2014); Allen (2015).

53 Pargman et al. (2016).
} 
Allen, D. (2015). The sharing economy. Institute of Public Affairs Review: A Quarterly Review of Politics and Public Affairs 67(3): 25-27.

Belk, R. (2010). Sharing. Journal of Consumer Research 36(5): 715-734.

Böckmann, M. (2013). The Shared Economy: It Is Time to Start Caring about Sharing; Value Creating Factors in the Shared Economy. University of Twente, Faculty of Management and Governance.

Borys, T. (2011). Zrównoważony rozwój - jak rozpoznać ład zintegrowany. Problemy Ekorozwoju 6(2): $75-81$.

Borys, T. (2012). Trwały i zrównoważony rozwój, [w:] W. Gasparski (red.), Biznes, etyka, odpowiedzialność. Warszawa: Wydawnictwo Naukowe PWN: 51-74.

Borys, T. (2014). Wybrane problemy metodologii pomiaru nowego paradygmatu rozwoju - polskie doświadczenia. Optimum. Studia Ekonomiczne 3/69: 3-21.

Botsman, R. (2013). The sharing economy lacks a shared definition. Fast Company 21.

Budziewicz-Guźlecka, A. (2017). Role of the sharing economy in the contemporary economy. Ekonomiczne Problemy Usług 1(126): 27-36.

Burford, G., Hoover, E., Velasco, I., Janoušková, S., Jimenez, A., Piggot, G., Podger, D., Harder, M.K. (2013). Bringing the "missing pillar" into sustainable development goals: towards intersubjective values-based indicators. Sustainability 5(7): 3035-3059.

Cohen, B., Kietzmann, J. (2014). Ride on! Mobility business models for the sharing economy. Organization \& Environment 27(3): 279-296.

Czernek, K., Wójcik, D. (2017). Gospodarka współdzielenia z perspektywy przedsiębiorców sektora turystycznego. Handel Wewnętrzny 3(368). Tom 1: 66-76.

Czernek, K., Wójcik, D., Marszałek, P. (2018). Zaufanie w gospodarce współdzielenia. Gospodarka Narodowa 3: 23-48.

Daunorienè. A., Drakšaitė. A., Snieška. V., Valodkienè. G. (2015). Evaluating sustainability of sharing economy business models. Procedia-Social and Behavioral Sciences 213: 836-841.

Dredge, D., Gyimóthy, S. (2015). The collaborative economy and tourism: critical perspectives, questionable claims and silenced voices. Tourism Recreation Research 40(3): 286-302.

Felson, M., Spaeth, J.L. (1978). Community structure and collaborative consumption: a routine activity approach. American Behavioral Scientist 21(4): 614-624.

Finkbeiner, M., Schau, E.M., Lehmann, M., Traverso, M. (2010). Towards life cycle sustainability assessment. Sustainability 2(10): 3309-3322.

Ganowicz-Bączyk, A. (2013). Ekonomia w służbie zrównoważonego rozwoju. Studia Ecologiae et Bioethicae 11(1): 29-45.

Gibson, R.B. (2006). Beyond the pillars: sustainability assessment as a framework for effective integration of social, economic and ecological considerations in significant decision-making. Journal of Environmental Assessment Policy and Management 8(3): 259-280.

Grosskurth, J., Rotmans, J. (2005). The scene model: getting grip on sustainable development in policy making. Environment, Development and Sustainability 7(1): 135-151.

Hamari, J., Sjöklint, M., Ukkonen, A. (2016). The sharing economy: why people participate in collaborative consumption. Journal of the Association for Information Science and Technology 67(9): 2047-2059.

Hatzopoulos, V., Roma, S. (2017). Caring for sharing? The collaborative economy under EU law. Common Market Law Review 54(1): 81-127.

Heinrichs, H. (2013). Sharing economy: a potential new pathway to sustainability. GAIA-Ecological Perspectives for Science and Society 22(4): 228-231.

Janczewski, J. (2017). Konsumpcja współdzielona a przedsiębiorczość. Przedsiębiorczość-Edukacja 13: 262-274.

Jastrzębska, E., Legutko-Kobus, P. (2017). Ekonomia współpracy - definicje, klasyfikacje i dobre praktyki. Zarządzanie Publiczne 40(4): 443-461.

Jeżowski, P. (2012). Rozwój zrównoważony i jego nowe wyzwania. Kwartalnik Kolegium Ekonomiczno-Społecznego Studia i Prace 2: 99-124.

Kiełczewski, D. (2010). Zrównoważony rozwój - istota, interpretacje, związek ze społeczeństwem wiedzy, [w:] B. Poskrobko (red.), Ekonomia zrównoważonego rozwoju. Materiały do studiowania. Białystok: Wydawnictwo Wyższej Szkoły Ekonomicznej w Białymstoku. 
Kiełczewski, D. (2011). Związki idei zrównoważonego rozwoju z ideą społecznej odpowiedzialności biznesu. Optimum. Studia Ekonomiczne 6(54): 21-31.

Koopman, C., Mitchell, M., Thierer, A. (2015). The sharing economy and consumer protection regulation: the case for policy change. Journal of Bussines, Entrepreneurship \& Law 8(2): $529-545$.

Koźlak, A. (2017). Sharing Economy jako nowy trend społeczno-gospodarczy. Prace Naukowe Uniwersytetu Ekonomicznego we Wrocławiu 489: 171-182.

Leszczyńska, M., Łopaciński, K. (2017). Współdzielenie i kokreacja jako przejawy nowych trendów w ekonomii. Informatyka Ekonomiczna 2(44): 82-93.

Machowski, J. (2003). Ochrona środowiska. Prawo i zrównoważy rozwój (Stan prawny na dzień 1 stycznia 2003 roku). Warszawa: Wydawnictwo Akademickie „Żak”.

Martin, C.J. (2016). The sharing economy: a pathway to sustainability or a nightmarish form of neoliberal capitalism? Ecological Economics 121: 149-159.

Nurse, K. (2006). Culture as the fourth pillar of sustainable development. Small States: Economic Review and Basic Statistics 11: 28-40.

Owyang, J., Tran, C., Silva, C. (2013). The Collaborative Economy. Altimeter, United States.

Parente, R.C., Geleilate, J.M.G., Rong, K. (2018). The sharing economy globalization phenomenon: a research agenda. Journal of International Management 24(1): 52-64.

Pargman, D., Eriksson, E., Friday, A. (2016). Limits to the sharing economy, [w:] Proceedings of the Second Workshop on Computing within Limits. ACM, New York: 1-7.

Pietrewicz, J.W., Sobiecki, G. (2016). Przedsiębiorczość sharing economy, [w:] M. Poniatowska-Jaksch, R. Sobiecki (red.), Sharing economy (gospodarka współdzielenia). Warszawa: Oficyna Wydawnicza SGH.

Poskrobko, B. (2011). Metodologiczne aspekty ekonomii zrównoważonego rozwoju, [w:] B. Poskrobko (red.), Ekonomia zrównoważonego rozwoju w świetle kanonów nauki. Białystok: Wydawnictwo Wyższej Szkoły Ekonomicznej w Białymstoku.

Rifkin, J. (2014). The zero marginal cost society: the internet of things, the collaborative commons, and the eclipse of capitalism. New York: St. Martin's Press.

Rostek, A., Zalega, T. (2015). Konsumpcja kolaboratywna wśród młodych polskich i amerykańskich konsumentów (cz. 1). Marketing i Rynek 5(22): 11-19.

Sachs, J.D. (2012). From millennium development goals to sustainable development goals. The Lancet 379(9832).

Scholz, T. (2014). Platform cooperativism vs. the sharing economy. Big Data \& Civic Engagement 47: 47-52.

Schor, J. (2016). Debating the sharing economy. Journal of Self-Governance and Management Economics 4(3): 7-22.

Seyfang, G. (2006). Sustainable consumption, the new economics and community currencies: developing new institutions for environmental governance. Regional Studies 40(5): 781-791.

Sobiecki, G. (2016). Sharing economy - dylematy pojęciowe, [w:] M. Poniatowska-Jaksch, R. Sobiecki (red.), Sharing economy (gospodarka współdzielenia). Warszawa: Oficyna Wydawnicza SGH.

Stanny, M., Czarnecki, A. (2011). Zrównoważony rozwój obszarów wiejskich Zielonych Płuc Polski. Próba analizy empirycznej. Warszawa: Polska Akademia Nauk.

Stępnicka, N. (2018). Sharing economy a ekonomia społeczna i ekonomia behawiarolna. Prace Naukowe Uniwersytetu Ekonomicznego we Wrocławiu 530: 46-54.

Stępnicka, N., Wiączek, P. (2018). Access economy i sharing economy w świetle teorii innowacji. Prace Naukowe Uniwersytetu Ekonomicznego we Wrocławiu 509: 396-405.

Stokes, K., Clarence, E., Anderson, L., Rinne, A. (2014). Making sense of the UK collaborative economy. London: Nesta.

Sun, J., Yan, J., Zhang, K.Z. (2016). Blockchain-based sharing services: what blockchain technology can contribute to smart cities. Financial Innovation 2(1): 1-9.

Sztokfisz, B. (2017). Gospodarka współdzielenia - pojęcie, źródła, potencjał. Zeszyty Naukowe Uniwersytetu Ekonomicznego w Krakowie 6(966): 89-103.

Sztumski, W. (2006). Idea zrównoważonego rozwoju a możliwości jej urzeczywistniania. Problemy Ekorozwoju 1(2): 73-76. 
Tornjanski, V., Marinkovic, S., Jancic, Z. (2017). Towards sustainability: effective operations strategies, quality management and operational excellence in banking. Amfiteatru Economic 19(44): 79-94.

Zgiep, Ł. (2014). Sharing economy jako ekonomia przyszłości. Myśl Ekonomiczna i Polityczna 4(47): 193-205.

Ziobrowska, J. (2017). Sharing economy jako nowy trend konsumencki, [w:] U. Kalina-Prasznic (red.), Własność w prawie i gospodarce. Wrocław: Wydawnictwo Uniwersytetu Wrocławskiego.

Zygmuntowski, J.J. (2017). Rewolucja platform wielostronnych. Refleksja nad gospodarka współdzielenia w świetle interesu publicznego, [w:] K. Kozłowski, J.J. Zygmuntowski (red.), \#FutureInsights: Technologie 4.0 a przemiany społeczno-gospodarcze. Warszawa: Oficyna Wydawnicza SGH: 13-32.

\section{THE PLACE OF THE SHARING PHENOMENON IN THE CONCEPT OF SUSTAINABLE DEVELOPMENT}

S u m m a r y

The aim of the article is to identify the place of the sharing phenomenon in the concept of sustainable development. Thus far, attempts to address the sharing phenomenon are very rarely connected with the concept of sustainable development. According to the author, considerations in this area should be based on the theory of sustainable economic development. This would be the best starting point for juxtaposing the sharing phenomenon with the classic conception of the market and its key concepts, such as homo oeconomicus.

Keywords: sharing phenomenon; sustainable development 
